\title{
Growth of robusta coffee after the application of herbicides to control Urochloa ruziziensis
}

\author{
Karolina Flôres da Silva1 (iD), Ricardo Moraes Shipitoski ${ }^{(1 D}$, Jhene Thais Dittmann da Costa1 (D), Barbara Olinda Nardis² (iD), \\ Paulo Sérgio de Souza ${ }^{1}$ (D), Lourismar Martins Araujo ${ }^{1}$ (D), Fabrício Ribeiro Andrade ${ }^{1}$ (iD
}

${ }^{1}$ Instituto Federal de Educação, Ciência e Tecnologia de Mato Grosso/IFMT, Juína, MT, Brasil

${ }^{2}$ Universidade Federal de Lavras/UFLA, Lavras, MG, Brasil

Contact authors: karolina.flores.flores@gmail.com, shipitoski@gmail.com, jhenethais@gmail.com, barbaraonardis@gmail.com, paulosergiobio12@gmail.com, lourismar.araujo@jna.ifmt.edu.br, fabricio.andrade@jna.ifmt.edu.br

Received in June 22, 2020 and approved November 25, 2020

\section{ABSTRACT}

The growth of coffee plants can be severely affected by competition with other plants, being necessary to the management of these, which can be performed by controls manual, mechanical, biological and chemical methods. This study aimed to evaluate the growth of coffee robusta due to no control of Urochloa ruziziensis (cv. Common) and control by manual weeding and herbicides in post emergence, seeking the most appropriate method. The experimental design was completely randomized, with four replicates of four treatments: control (no control of the $U$. ruziziensis); manual weeding;

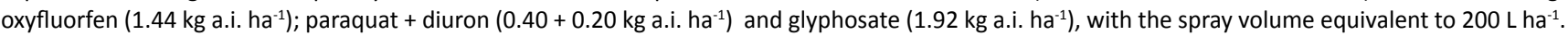
The herbicides were applied directly on the $U$. ruziziens plants 60 days after planting. 30 days after treatment, the following were evaluated: $a, b$ and total chlorophyll content, stem diameter, plant height, number of leaves, leaf area, orthotropic and plagiotropic branches, dry shoot biomass, dry root biomass and root growth. $U$. ruziziens, when not controlled, caused a $42 \%$ reduction in the leaf area of robusta coffee in relation to those that were controlled through manual weeding. The herbicide oxyfluorfen and weeding were the most suitable for the control of $U$. ruziziens in the cultivation of coffee, since they did not affect seedling growth. Failure to control $U$. ruziziens or weeds leads to reduced growth of robusta coffee plants, except in the height due to the etiolation caused by competition with $U$. ruziziens.

Key words: Coffea canephora Pierre ex Froehner; Coffee seedlings; Brachiaria; Chemical control.

\section{INTRODUCTION}

The coffee agribusiness has a prominent position in the Brazilian economy due to being an important source of jobs and income (Silva et al., 2017; Castanheira et al., 2019). In Brazil there are 370 thousand hectares under robusta coffee cultivation. The state of Mato Grosso is the new agricultural expansion frontier, growing at a rate of $20 \%$ per year due to the conducive edaphoclimatic conditions of the Amazon region. The state has 9,900 hectares under cultivation and an average productivity of 17 bags ha-1 (Companhia Nacional de Abastecimento - CONAB, 2020).

According to Castanheira et al. (2019), coffee productivity is related to several factors, such as soil fertility, nutrient availability, phytosanitary controls, climatic conditions, the use of technologies and proper weed management. The latter being an extremely important factor when considering the rapid development of seedlings following transplanting. It is worth noting that the majority of the coffee plant root system is concentrated in the soil close to the stem and goes down to $0.30 \mathrm{~m}$ deep (Ronchi et al., 2015). Thus, weed management of newly planted crops to reduce inter-species competition is an extremely important activity in the coffee production system (Borges et al., 2019).

Currently, many producers work with a concept of companion planting in coffee plantations, using a combination of coffee and Urochloa ruziziensis (R. Germ. and C.M. Evrard) Crins. The forage is grown between the rows of coffee plants. During transplanting of the coffee seedlings, the U. ruziziens is controlled with herbicide, then mowed and the plant matter is left between the rows as mulch (Ragassi; Pedrosa; Favarin, 2013). The practice of intercropping with $U$. ruziziens and coffee is effective. It decreases the competition from other weeds, generates soil cover, and increases the availability of nutrients due to the decomposing straw, thus increasing fertility and the amount of organic matter in the soil (Pedrosa et al., 2014).

However, there are a limited number of herbicides registered for the control of U. ruziziens on coffee farms. The lack of selective herbicides for use around young coffee trees has led producers to use non-selective products (e.g. glyphosate and paraquat) directly on the weed. Glyphosate, paraquat, diuron and oxyfluorfen are some of the main herbicides used to control weeds in coffee culture (Plese; Silva; Foloni, 2009), being an alternative for controlling $U$. ruziziens in intercropped systems. The application of non-selective herbicides can negatively affect the coffee seedlings due to drift, causing phytotoxicity (Voltolini et al., 2019), leading to morphological and physiological changes in the plants and, consequently, causing nutritional disorders which can be visually diagnosed through the incidence of chlorotic or diminished growth (Silva et al., 2017). 
Studies that seek to evaluate herbicide performance on the control of $U$. ruziziens and to quantify their effects on the growth of coffee seedlings can inform economic and productivity gains for robusta coffee farms. Thus, this study aimed to evaluate the growth of coffee robusta due to no control of $U$. ruziziensis (cv. Common) and control by manual weeding and herbicides in post emergence, seeking the most appropriate method.

\section{MATERIAL AND METHODS}

The experiment was conducted in a greenhouse with a transparent polyethylene cover and protected on the sides with $50 \%$ shading. The experiment took place at the Federal Institute of Education, Science and Technology of Mato

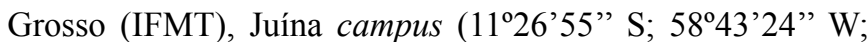
$320 \mathrm{~m}$ altitude), from August 2019 to January 2020. Pots of $3.5 \mathrm{dm}^{3}$ were filled with soil collected from the top $0-0.20 \mathrm{~m}$ layer of a clayey Oxisol ("Latossolo Vermelho", according to the Brazilian classification system). The soil was air-dried and sieved in a $4 \mathrm{~mm}$ mesh, being chemically and textural characterized (Table1).

Pre-planting fertilization was carried out following recommendations outlined by Malavolta (1980). Fertilizers were applied in the following concentrations: $1.0 \mathrm{e}^{-4} \mathrm{~kg} \mathrm{~kg}^{-1}$ of $\mathrm{N}, 4.0 \mathrm{e}^{-4} \mathrm{~kg} \mathrm{~kg}^{-1}$ of $\mathrm{P}, 1.0 \mathrm{e}^{-4} \mathrm{~kg} \mathrm{~kg}^{-1}$ of $\mathrm{K}_{2} \mathrm{O}$ and $5.0 \mathrm{e}^{-5} \mathrm{~kg} \mathrm{~kg}^{-1}$ of $\mathrm{S}$, using ammonium phosphate monobasic $\left(\mathrm{NH}_{4} \mathrm{H}_{2} \mathrm{PO}_{4}\right)$, potassium chloride $(\mathrm{KCl})$; ammonium nitrate $\left(\mathrm{NH}_{4} \mathrm{NO}_{3}\right)$ and magnesium sulfate $\left(\mathrm{MgSO}_{4} \cdot 7 \mathrm{H}_{2} \mathrm{O}\right)$. Micronutrients were applied in the following concentrations: $5.0 \mathrm{e}^{-7} \mathrm{~kg} \mathrm{~kg}^{-1}$ boron, $1.5 \mathrm{e}^{-6} \mathrm{~kg} \mathrm{~kg}^{-1}$ copper, $1.0 \mathrm{e}^{-7} \mathrm{~kg} \mathrm{~kg}^{-1}$ molybdenum and $5.0 \mathrm{e}^{-6} \mathrm{~kg}$ $\mathrm{kg}^{-1}$ zinc, in the form of boric acid $\left(\mathrm{H}_{3} \mathrm{BO}_{3}\right)$, copper sulfate $\left(\mathrm{CuSO}_{4} \cdot 5 \mathrm{H}_{2} \mathrm{O}\right)$, ammonium molybdate $\left[\left(\mathrm{NH}_{4}\right) 6 \mathrm{Mo}_{7} \mathrm{O}_{24} \cdot 4 \mathrm{H}_{2} \mathrm{O}\right]$ and zinc sulfate $\left(\mathrm{ZnSO}_{4} \cdot 7 \mathrm{H}_{2} \mathrm{O}\right)$. A blanket fertilization was applied 60, 90 and 120 days after transplantation (DAT) of $50 \mathrm{mg}$ of $\mathrm{N}$ and $\mathrm{K}$, using ammonium nitrate and potassium chloride.
After fertilization, healthy and acclimated clonal robusta seedlings (var. BRS Ouro Preto) were transplanted into pots. They were transplanted from $0.5 \mathrm{dm}^{3}$ plastic bags with commercial substrate and at the time of transplanting had on average eight pairs of leaves and were $25 \mathrm{~cm}( \pm$ $3 \mathrm{~cm}$ ) tall. After transplanting, humidity was maintained at $80 \%$ pot capacity to encourage seedling establishment and development. At 90 DAT, when the plants showed uptake and initial development, the $U$. ruziziensis, was sown at a $0.04 \mathrm{~m}$ depth. Ten seeds were placed in each pot and thinning took place ten days after emergence, leaving five plants per pot. At 150 DAT of the coffee seedlings and 60 days after planting the $U$. ruziziens, the treatments to control the were applied.

The experimental design was completely randomized, with four replications and five treatments: control (no control of the $U$. ruziziens); manual weeding; oxyfluorfen $(1.44 \mathrm{~kg}$ a.i. $\left.\mathrm{ha}^{-1}\right)$; paraquat + diuron $\left(0.40+0.20 \mathrm{~kg}\right.$ a.i. $\left.\mathrm{ha}^{-1}\right)$ and glyphosate $\left(1.92 \mathrm{~kg}\right.$ a.i. ha $\left.{ }^{-1}\right)$. The herbicides were applied using a pressurized $\mathrm{CO}_{2}$ backpack sprayer fitted nozzle and fan type spray volume equivalent to $200 \mathrm{~L} \mathrm{ha}^{-1}$.

The aboveground part of the coffee plant was covered before uniformly spraying all the leaves of the $U$. ruziziens plants. Manual weeding was performed by cutting the $U$. ruziziens plants below the tiller.

At 30 days after the application of the treatments, $a, b$ and total chlorophyll content was evaluated using the chlorophyll meter ClorofiLOG, model CFL 1030 (Falker ${ }^{\circledR}$ ), sampling the central point of the leaf used for measurement. The diameter was measured at the start of the stem using a digital caliper with an accuracy of $3 \mathrm{e}^{-5} \mathrm{~m}$. The plant height was calculated in millimeters from the surface of the soil to the shoot apex with the aid of a ruler.

The number of leaves was obtained directly through counting and the leaf area was calculated using the method proposed by Flumignan, Adami and Faria (2008) (Equation 1):

$$
\text { LAld }=0.6751 \times(\mathrm{L} \times \mathrm{W})+0.3533
$$

Table 1: Chemical and textural characterization of soil.

\begin{tabular}{|c|c|c|c|c|c|c|c|}
\hline \multirow{2}{*}{$\begin{array}{c}\mathrm{pH} \\
\left(\mathrm{H}_{2} \mathrm{O}\right)\end{array}$} & $\mathrm{H}+\mathrm{Al}^{3+}$ & $\mathrm{Al}^{3+}$ & $\mathrm{P}$ & $\mathrm{K}$ & $\mathrm{S}$ & $\mathrm{Ca}$ & $\mathrm{Mg}$ \\
\hline & $\mathrm{cmol}_{\mathrm{c}} \mathrm{dm}^{-3}$ & $\mathrm{cmol}_{\mathrm{c}} \mathrm{dm}^{-3}$ & $\mathrm{mg} \mathrm{dm}{ }^{-3}$ & $\mathrm{mg} \mathrm{dm}{ }^{-3}$ & $\mathrm{mg} \mathrm{dm}^{-3}$ & $\mathrm{cmol}_{\mathrm{c}} \mathrm{dm}^{-3}$ & $\mathrm{cmol}_{\mathrm{c}} \mathrm{dm}^{-3}$ \\
\hline 6.7 & 1.70 & 0.0 & 6.90 & 86.0 & 6.0 & 7.86 & 1.50 \\
\hline B & $\mathrm{Cu}$ & $\mathrm{Mn}$ & $\mathrm{Zn}$ & $\mathrm{Fe}$ & SB & CEC & $\mathrm{V}$ \\
\hline $\mathrm{mg} \mathrm{dm}^{-3}$ & $\mathrm{mg} \mathrm{dm}{ }^{-3}$ & $\mathrm{mg} \mathrm{dm}^{-3}$ & $\mathrm{mg} \mathrm{dm}^{-3}$ & $\mathrm{mg} \mathrm{dm}^{-3}$ & $\mathrm{cmol}_{\mathrm{c}} \mathrm{dm}^{-3}$ & $\mathrm{cmol}_{\mathrm{c}} \mathrm{dm}^{-3}$ & $\%$ \\
\hline 0.15 & 1.4 & 31.3 & 4.0 & 20.0 & 9.4 & 11.1 & 84.70 \\
\hline \multicolumn{2}{|c|}{ Organic matter } & \multicolumn{2}{|c|}{ Clay } & \multicolumn{2}{|c|}{ Silt } & \multicolumn{2}{|c|}{ Sand } \\
\hline \multicolumn{2}{|c|}{$\mathrm{kg} \mathrm{kg}^{-1}$} & \multicolumn{2}{|c|}{$\mathrm{kg} \mathrm{kg}^{-1}$} & \multicolumn{2}{|c|}{$\mathrm{kg} \mathrm{kg}^{-1}$} & \multicolumn{2}{|c|}{$\mathrm{kg} \mathrm{kg}^{-1}$} \\
\hline \multicolumn{2}{|c|}{$28.1 \mathrm{e}^{-3}$} & \multicolumn{2}{|c|}{0.60} & \multicolumn{2}{|c|}{0.18} & \multicolumn{2}{|c|}{0.22} \\
\hline
\end{tabular}

$\mathrm{pH}\left(\mathrm{H}_{2} \mathrm{O}\right)$ : Soil:water 1:2,5. P and K: Mehlich 1 extractor. $\mathrm{Ca}$, Mg e Al: KCl 1 mol L-1 extractor. CEC: Cation-exchange capacity. Organic matter: Walkley-Black method. V: Base saturation. Clay, silt and sand: Pipette method. 
where LAld is the estimated leaf area estimated by the method, $\mathrm{L}$ is the maximum length and $\mathrm{W}$ is the maximum width of the leaf.

Then, the coffee plants were separated by shoot and root biomass. The roots were washed under running water to remove excess soil, and the length of the roots was measured in millimeters with a ruler. The roots and shoots were placed in paper bags and taken to a forced circulation oven for 72 hours at $65{ }^{\circ} \mathrm{C}$, then weighed in an analytical balance with an accuracy of $1.0 \mathrm{e}^{-6} \mathrm{~kg}$ to determine the dry mass of the roots and shoot biomass. The $U$. ruziziens was collected and determined the plant height, number of tillers, shoot and root dry biomass, just as coffee plants.

In all the data sets considered, the distribution of the data was analyzed using the Anderson-Darling test and the homoscedasticity of the data verified with the equality of variance test (or Levene's test). The data obtained for each variable were subjected to analysis of variance $(p \leq 0.05)$ and their means were compared using the Tukey test $(p<0.05)$, using the statistical program R 3.2.3.

\section{RESULTS}

The application of treatments for the control of $U$. ruziziens were efficient, promoting their complete elimination, leaving only plants with good growth in the control treatment (Table 2).

The treatments to control or not the $U$. ruziziens significantly influenced the content of $a, b$ and total chlorophyll in the robusta coffee plants (Figure 1), where the non-control of the $U$. ruziziens resulted in the lowest levels of chlorophyll. The robusta coffee plants submitted to the application of the herbicide oxyfluorfen, for the control of the $U$. ruziziens, presented the highest values for $a, b$ and total chlorophyll. However, no significant difference was found when compared to the other treatments for controlling $U$. ruziziens, with the exception of no control.

The diameter of the coffee plant stem was not altered by the application of treatments (Figure 2A). The lowest plant heights were observed in specimens that were treated with herbicides. The control group and the specimens subjected to manual weeding were among the highest. However, only the plants treated with glyphosate were significantly shorter than the control (Figure 2B).

The largest number of leaves were recorded on the manual weeding treatment group and the group treated with herbicides oxyfluorfen and paraquat + diuron for the control of $U$. ruziziens (Figure 2C), differing significantly from the control group (no control of the U. ruziziens). The competition caused by the presence of $U$. ruziziens plants caused a reduction in the leaf area of the robusta coffee plants (Figure 2D). Not controlling the growth of the $U$. ruziziens caused a $42 \%$ reduction in the leaf area of the coffee plant when compared to the manual weeding treatment group.

The number of orthotropic branches did not change across control and treatment groups (Figure 3A). The number of plagiotropic branches was lower in the control group compared to the other treatment groups. However, the difference was only statistically significant compared to the group treated with oxyfluorfen (Figure 3B).

The shoot dry biomass was affected by the treatments applied to the coffee plants to control or not control the $U$. ruziziens (Figure 4A and 5). The manual weeding promoted the highest dry biomass values for the shoot. However, the manual weeding treatment group values were only significantly different from the control group, and not from the treatment groups subjected to chemical controls for the $U$. ruziziens. Non-controlling for $U$. ruziziens reduced the dry biomass of the coffee plant by $38 \%$ when compared to plants subject to manual weeding.

Dry root biomass was not affected by treatments to control or not control the $U$. ruziziens (Figure 4B). However, was observed larger root length (Figure 4C and 5). The longest roots were observed in coffee plants that were grown in competition with $U$. ruziziens, and the shortest root length was observed in the glyphosate control (Figure 4C).

Table 2: Growth of cultivated U. ruziziens associated with robusta coffee plants.

\begin{tabular}{ccccc}
\hline Treatments & Height of plants & Number of tillers & Root dry biomass & Shoot dry biomass \\
\cline { 2 - 5 } & $\mathrm{m}$ & units & $\mathrm{kg}$ & $\mathrm{kg}$ \\
\hline Control & $0.88 \pm 0.032$ & $11.75 \pm 1.78$ & $0.24 \mathrm{e}^{-3} \pm 4.7 \mathrm{e}^{-4}$ & $17.22 \mathrm{e}^{-3} \pm 4.82 \mathrm{e}^{-3}$ \\
Manual weeding & $0.0 \pm 0.0$ & $0.0 \pm 0.0$ & $0.0 \pm 0.0$ & $0.0 \pm 0.0$ \\
Oxyfluorfen & $0.0 \pm 0.0$ & $0.0 \pm 0.0$ & $0.0 \pm 0.0$ & $0.0 \pm 0.0$ \\
Paraquat + diuron & $0.0 \pm 0.0$ & $0.0 \pm 0.0$ & $0.0 \pm 0.0$ & $0.0 \pm 0.0$ \\
Glyphosate & $0.0 \pm 0.0$ & $0.0 \pm 0.0$ & $0.0 \pm 0.0$ & $0.0 \pm 0.0$ \\
\hline
\end{tabular}

\pm standard error of average values $(n=4)$. 

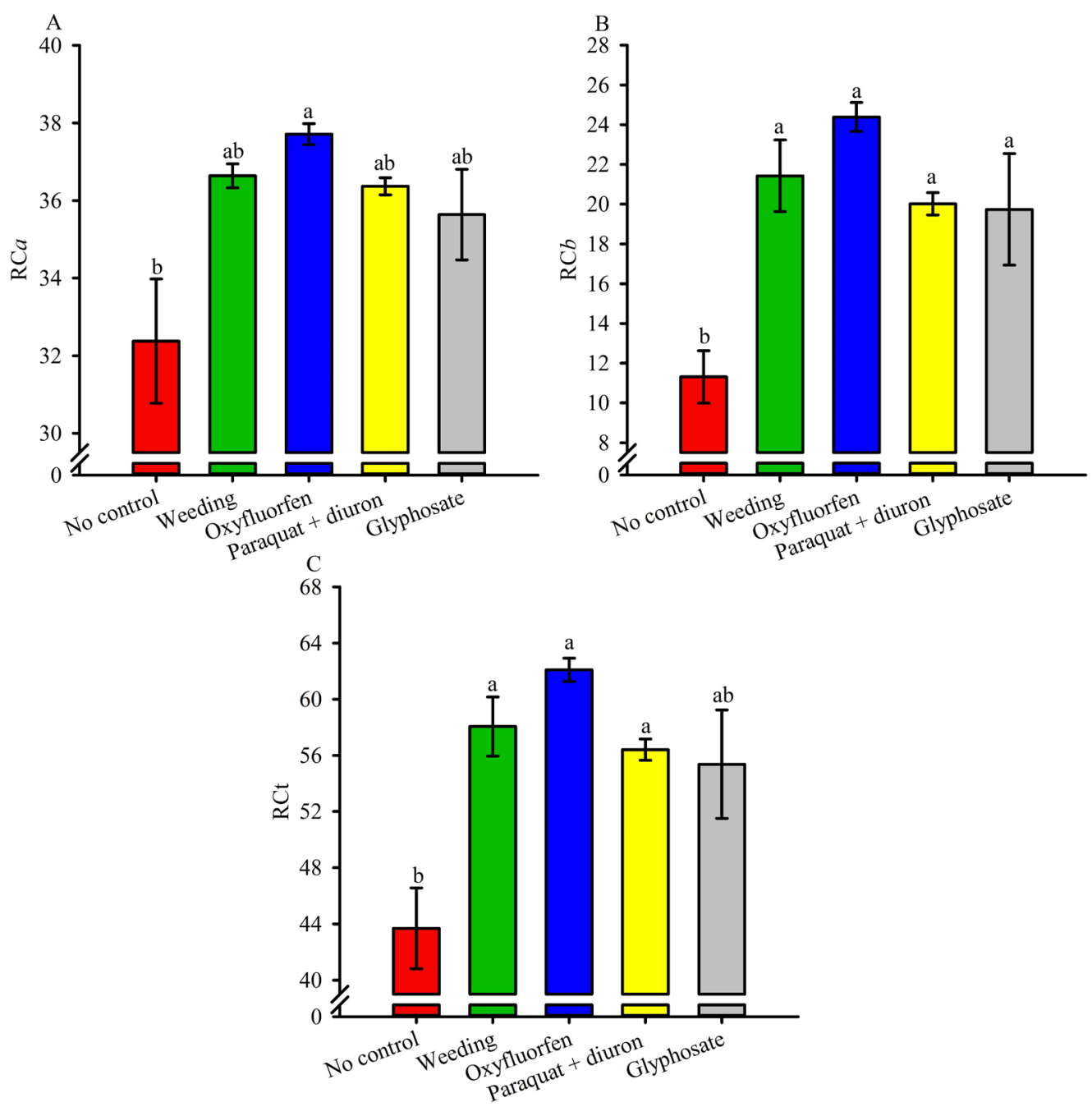

Figure 1: Relative content of chlorophyll $a(A), b(B)$ and total $(C)$ in robusta coffee as a function of treatments applied to control $U$. ruziziens. Mean values labeled with the same letter do not differ from each other according to Tukey's test (5\% probability). Vertical bars indicate the standard error of the mean $(n=4)$.

\section{DISCUSSION}

U. ruziziens control using herbicides and manual weeding were already expected, since herbicides are indicated for the control of $U$. ruziziens. The non-control of the $U$. ruziziens resulted in high competition with coffee, due to the high rate of absorption of nutrients and growth of the species (Table 2 and Figure 5).

Reduction in chlorophyll content in coffee plants, where was the non-control of the $U$. ruziziens (Figura 1) can be explained by the competition for light and nutrients with the $U$. ruziziens plants in the same environment. According to Amaral et al. (2015), the existence of two or more plants in the same environment generates competition for essential resources, such as available nutrients. The chlorophyll content present in the leaves was measured because it is the main factor determining photosynthetic activity. Therefore, the deficiency of a nutrient caused by competition between two or more species will lead to a reduction in chlorophyll, causing deficiency in glucose production and consequently limiting the development of the species involved (Silva et al., 2019). The relative chlorophyll content measured by portable equipment has a high correlation with the $\mathrm{N}$ content in the sheet as demontrado by Godoy et al. (2009), being indicative of the limited supply of nitrogen to be essential for chlorophyll synthesis.

The best response of the application of the herbicide oxyfluorfen may be related to the low toxicity of this herbicide to coffee plants, as pointed out in the study by Magalhães et al. (2012) where they found that the application of oxyfluorfen on the whole planted area (including on coffee plants) when applied later, after transplanting namely, resulted in a lower impairment of coffee growth. The diameter of the specimens comprises the secondary growth of the plant, it is, therefore, very slow and little influenced by the applications or nonapplications of herbicides. 

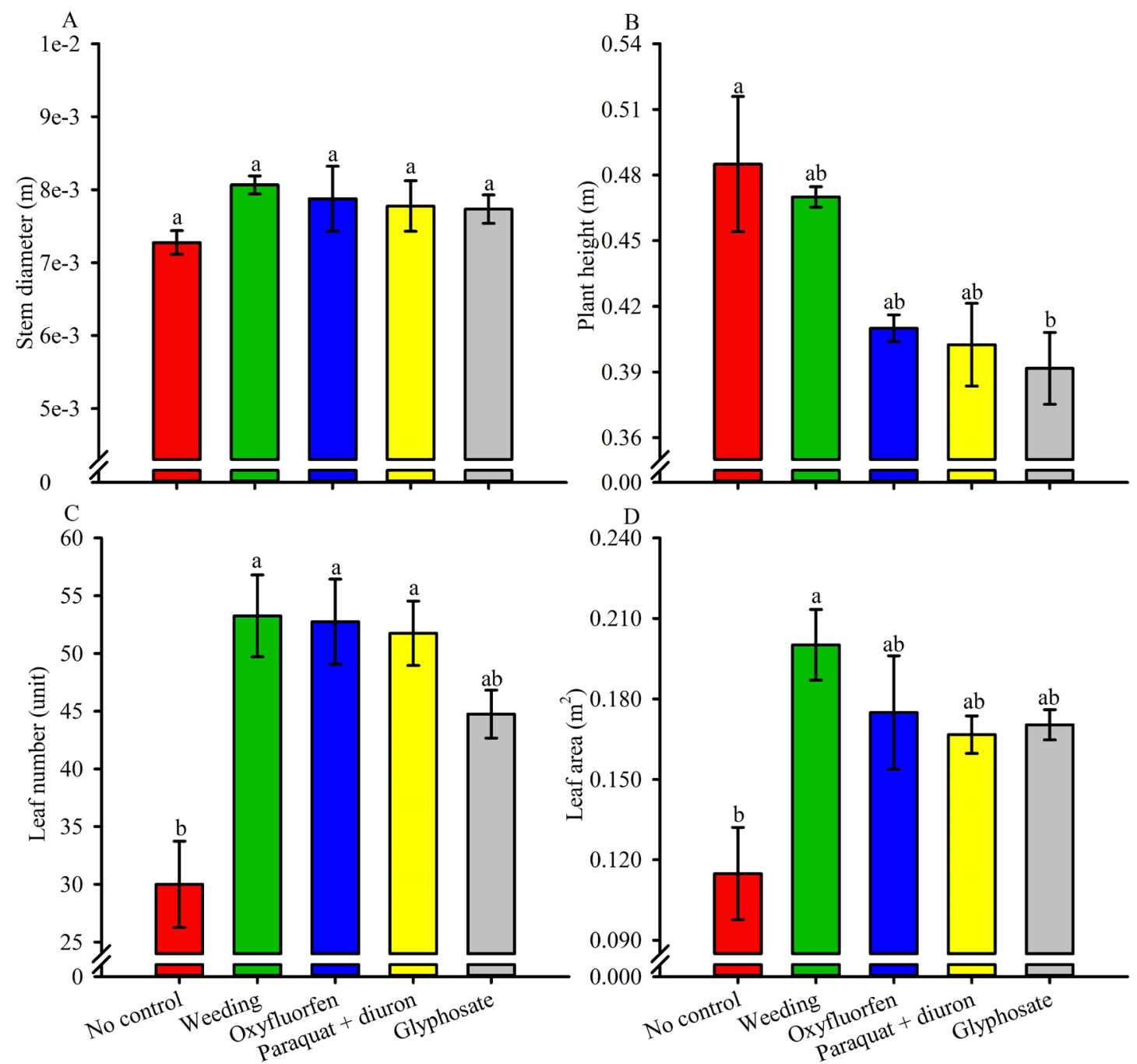

Figure 2: Growth of the coffee plant with respect to $U$. ruziziens control methods. Mean values labeled with the same letter do not differ from each other according to Tukey's test ( $5 \%$ probability). Vertical bars indicate the standard error of the mean $(n=4)$.
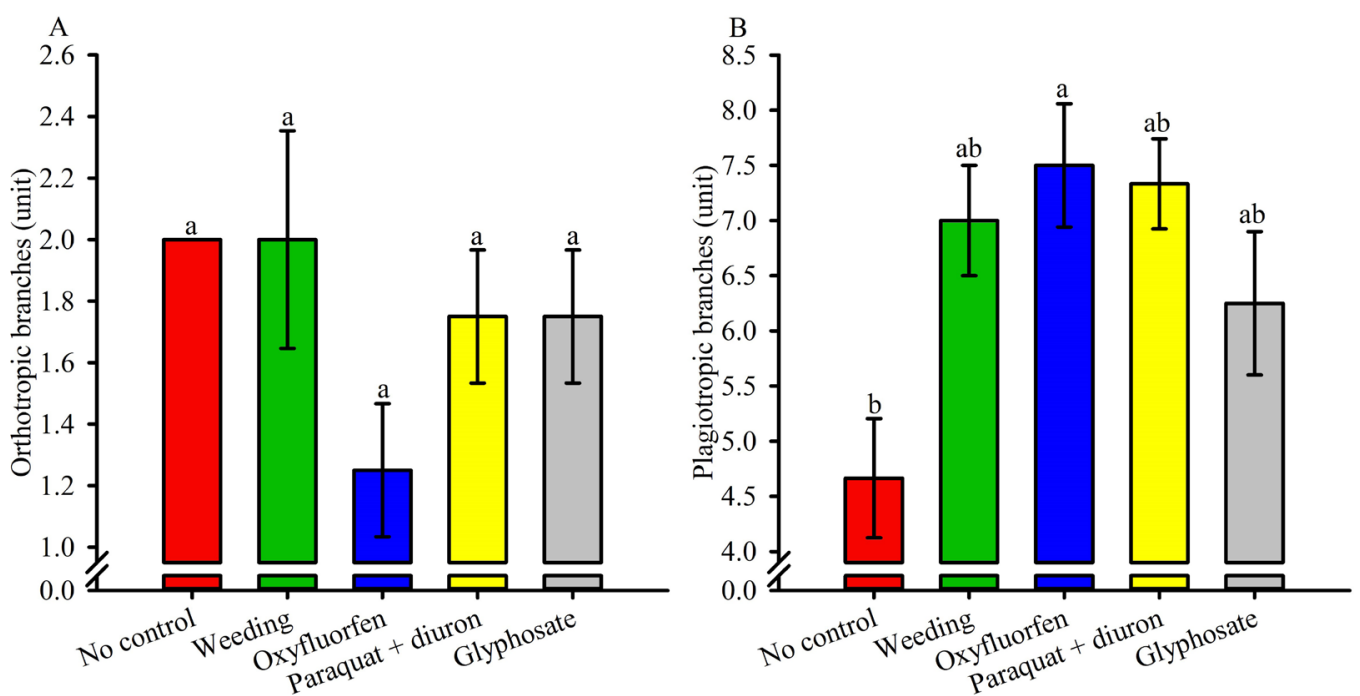

Figure 3: Orthotropic (A) and plagiotropic (B) branches of the coffee plant depending on the U. ruziziens control treatments. Mean values labeled with the same letter do not differ from each other according to Tukey's test ( $5 \%$ probability). Vertical bars indicate the standard error of the mean $(n=4)$. 


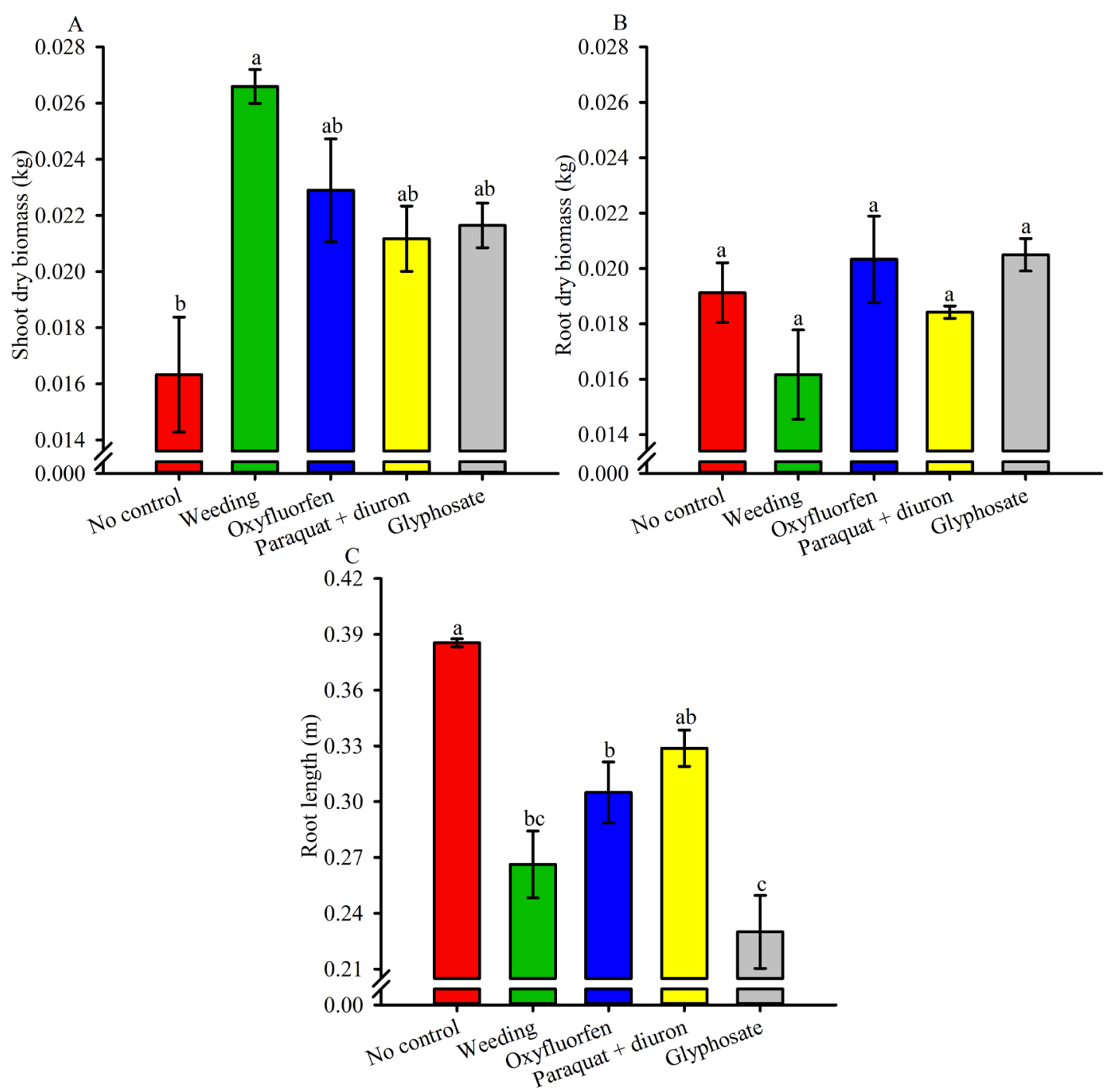

Figure 4: Dry biomass of the shoot $(A)$, roots $(B)$ and root length $(C)$ of the coffee plants depending on the treatments applied to control the U. ruziziens. Mean values labeled with the same letter do not differ from each other according to Tukey's test $(5 \%$ probability). Vertical bars indicate the standard error of the mean $(n=4)$.

The increased height of the coffee plants that did not receive treatment (weeding or herbicide) may be the induce of etiolation due to the growth competition exerted by the $U$. ruziziens. The greater height of coffee plants when in competition with $U$. ruziziens is related to the orthotropic branch etiolation, which is related to the reduction in the transport speed of auxins that promote cellular elongation in response to light (phototropism), thus the greater accumulation of this hormone on the shoots of plants results in higher etiolation as described by (De Biasi, 1996). The loss of chlorophyll is one of the most obvious morphological effects of etiolation (Figure 1).

The shorter plants, those in the glyphosate treatment, may have had their growth impaired by the herbicide as it acts on the secondary metabolism of the plant (Vidal, 1997). This may be related to glyphosate transfer through the exudates from the roots of $U$. ruziziens for the coffee roots. Tuffi Santos et al. (2005) studying the root exudate of glyphosate by $U$. decumbens was found that the transfer of 14C-glyphosate to Eucalyptus plants. Castanheira et al. (2019) studying the effect of simulated glyphosate drift on coffee plants (Coffea arabica L.) found that even minimal contact with the herbicide caused a reduction in plant height. Fialho et al. (2011) found a 38 and $33 \%$ reduction in the growth of coffee plants when they were being grown in the presence of Mucuna aterrima Piper \& Tracy and Brachiaria plantaginea (Link) Hitch respectively, which differs from the results obtained in this study. 

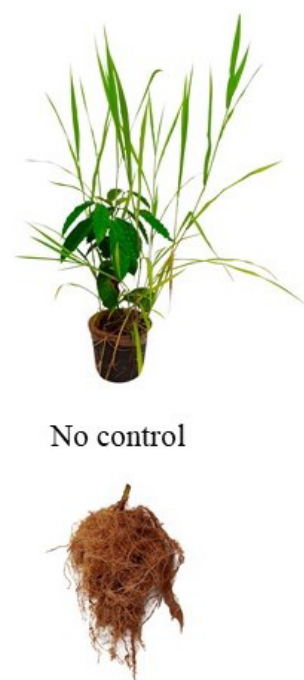

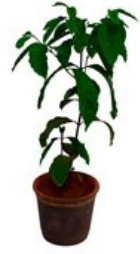

Weeding

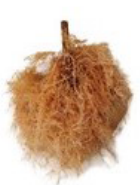

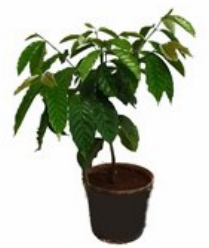

Oxyfluorfen

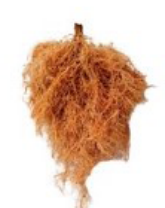

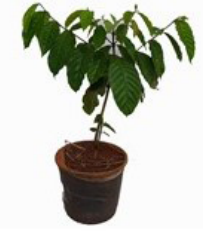

Paraquat + Diuron

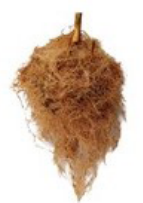

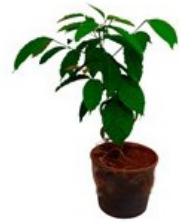

Glyphosate

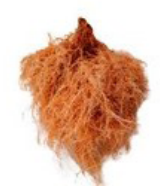

Figure 5: Growth of shoot and root of coffee in different methods of control or no of U. ruziziens.

The reduction in the number of leaves and leaf area in coffee plants caused by non-control of the U. ruziziens was reported by Fialho et al. (2011) when demonstrating that coffee is severely affected by the presence of Brachiaria decumbens. According to Fleck et al. (2009) the leaf area is the most important morphological characteristic and is related to the ability of plants to cover the soil and, most importantly, maximize their use of solar radiation for photosynthesis. Therefore, the smaller leaf area occurring when $U$. ruziziens is not controlled may reduce growth and consequently reduce coffee productivity when reaching reproductive maturity.

The smaller number of plagiotropic branches in coffee plants grown in the same environment as the $U$. ruziziens (Figure 3), is related to competition for space and nutrients, where the coffee plant seeks to prioritize the growth of orthotropic branches. This can result in less grain production, since plagiotropic branches are responsible for grain production. There are conflicting results in the literature regarding the use of the herbicide oxyfluorfen to control weeds in coffee. Yamashita et al. (2013) verified strong impacts on the shoots of $C$. canephora Pierre ex Froehner seedlings caused by $0.24 \mathrm{~kg}$ a.i. ha ${ }^{-1}$ doses of the herbicide oxyfluorfen. On the other hand, Silva et al. (2017) and Pucci et al. (2019) found that the growth of Arabica coffee seedlings (Coffea arabica L.) was not affected by oxyfluorfen, despite causing phytotoxicity and minor injuries to the plant because it is selective herbicide for this species.

The reduction in the shoot dry biomass of the coffee plant is related to the reduction of the leaf area in plants that were grown in competition with the $U$. ruziziens (Figure 2D). This is also reflected by the high growth rate of the $U$. ruziziens (Table 2) that produced more shoot dry biomass than the robusta coffee plants. When comparing total productivity, adding the shoot biomass of the coffee and the $U$.ruziziens, the result is $26 \%$ higher than specimens for which the $U$. ruziziens was controlled by the herbicide oxyfluorfen. Fialho et al. (2011) demonstrated in their study that coffee plants affected by competition with Brachiaria decumbens at a density of six plants per pot, presented lower total dry biomass, with a difference of $37.8 \%$ compared to plants free from interference.

The longer roots of coffee plants cultivated with $U$. ruziziens may be related to the greater development of the root system, since competition for nutrients and oxygen can stimulate root growth. According to Rajcan and Swanton (2001), in response to competition, there may be changes in the partition of photoassimilates, with morphological changes in the plant, such as increased root growth in relation to biomass production in the initial stage of crop development. This is an attempt by the plant to invest in a certain function, due to the lack of mineral resources hampering homogeneous growth (Poorter; Nagel, 2000).

\section{CONCLUSIONS}

Failure to control $U$. ruziziens causes a reduction in the growth of robusta coffee plants, except in the height due to the etiolation caused by competition with $U$. ruziziens. Manual weeding and chemical control using the herbicide oxyfluorfen are the most suitable for $U$. ruziziens control, since they do not harm the growth of robusta coffee plants.

\section{ACKNOWLEDGMENTS}

The authors express their gratitude to the National Council for Scientific and Technological Development (CNPq), the Mato Grosso State Research Support Foundation (Fapemat) and the Federal Institute of Education, Science and Technology of Mato Grosso for the scholarships granted and 
financial support. To Eder Luis Weber and the Department of Agriculture and Environment of the municipality of Juína for the supply of seedlings of robusta coffee and for their assistance in conducting the experiment.

\section{REFERENCES}

AMARAL, C. L. et al. Relações de interferência entre plantas daninhas e a cultura do grão-de-bico. Bioscience Journal, 31(1):37-46, 2015.

BIASI, L. A. Emprego do estiolamento na propagação de plantas. Ciência Rural, 26(2):309-314, 1996.

BORGES, L. G. M. et al. Response of arabica coffee cultivars to competition from beggarticks. Planta Daninha, 37:e019213814, 2019.

CASTANHEIRA, D. T. et al. Grow, anatomy and physiology of coffee plants intoxicated by the herbicide glyphosate. Coffee Science, 14(1):76-82, 2019.

\section{COMPANHIA NACIONAL DE ABASTECIMENTO} - CONAB. Acompanhamento da safra brasileira café safra 2020: Primeiro levantamento, janeiro/2020. Brasília, 2020. 62p.

FIALHO, C. M. T. et al. Interferência de plantas daninhas sobre o crescimento inicial de Coffea arabica. Planta Daninha, 29(1):137-147, 2011.

FLECK, N. G. et al. Avaliação de características de planta em cultivares de aveia com habilidade competitiva. Planta Daninha, 27(2):211-220, 2009.

FLUMIGNAN, D. L.; ADAMI, M.; FARIA, R. T. Área foliar de folhas íntegras e danificadas de cafeeiro determinada por dimensões foliares e imagem digital. Coffee Science, 3(1):1-6, 2008.

MAGALHÃES, C. E. O. et al. Seletividade e controle de plantas daninhas com oxyfluorfen e sulfentrazone na implantação de lavoura de café. Planta Daninha, 30(3):607-616, 2012.

MALAVOLTA, E. Elementos da nutrição mineral de plantas. São Paulo: Ceres, 1980. 251p.

PEDROSA, A. W. et al. Resíduo de Brachiaria fertilizada com nitrogênio na adubação do cafeeiro. Coffee Science, 9(3):366-373, 2014.
PLESE, L. P. M.; SILVA, C. L.; FOLONI, L. L. Distribuição nos compartimentos ambientais dos herbicidas utiilizados nas culturas de algodão, café e citros. Planta Daninha, 27(1):123-132, 2009.

POORTER, H.; NAGEL, O. The role of biomass allocation in the growth response of plants to different levels of light, $\mathrm{CO}_{2}$, nutrients and water: A quantitative review. Australian Journal of Plant Physiology, 27(6):595-607, 2000.

PUCCI, L. F. et al. Association of indaziflam and oxyfluorfen in coffee pre-transplantation. Coffee Science, 14(3):359$365,2019$.

RAGASSI, C. F.; PEDROSA, A. W.; FAVARIN, J. L. Aspectos positivos e riscos no consórcio cafeeiro e braquiária. Revista Visão Agrícola, 8(12):29-32, 2013.

RAJCAN, I.; SWANTON, C. J. Understanding maize-weed competition: Resource competition, light quality and the whole plant. Field Crops Research, 71(2):139-150, 2001.

RONCHI, C. P. et al. Morfologia radicular de cultivares de café arábica submetidas a diferentes arranjos espaciais. Pesquisa Agropecuária Brasileira, 50(3):187-195, 2015.

SILVA, L. G. et al. Sintomas de fitotoxicidade e crescimento de mudas de café submetidas aos herbicidas inibidores da Protox. Coffee Science, 12(3):290-296, 2017.

SILVA, P. V. et al. Chemical control strategies of commelina benghalensis in coffee crop. Coffee Science, 14(2):231$239,2019$.

TUFFI SANTOS, L. D. et al. Exsudação radicular do glyphosate por Brachiaria decumbens e seus efeitos em plantas de eucalipto e na respiração microbiana do solo. Planta Daninha, 23(1):143-152, 2005.

VIDAL, R. A. Herbicidas: Mecanismos de ação e resistência de plantas. Porto Alegre: 1997. 165p.

VOLTOLINI, G. B. et al. Phytotoxicity and growth of coffee plants as a funcction of the application of herbicide 2,4-D. Coffee Science, 14(4):438-445, 2019.

YAMASHITA, O. M. et al. Deriva simulada de herbicidas em mudas de Coffea canephora. Scientia Agraria Paranaensis, 12(2):148-156, 2013. 